\title{
Good news for German genome research...
}

Alison Abbott, Munich

Last week's announcement of the draft sequence of the human genome has prompted politicians in both Germany and Italy to publish papers on national programmes of genome research that had been gathering dust for many months.

German scientists have welcomed the federal research ministry's plan for a significant increase in support for such research. But their Italian colleagues are dismayed by support for a bill introduced into the country's senate creating a politically controlled oversight committee that would be responsible for all aspects of genome research (see story below).

Germany came to the genomics game late; the German Human Genome Project (DHGP) was launched, with limited public funds, in only 1996. But research minister Edelgard Bulmahn, who was originally sceptical about the importance of genomics, has been persuaded otherwise, primarily through the persistent efforts of her secretary of state Wolf-Michael Catenhusen.

As a result, the ministry this week published a detailed financing plan for the next four years which envisages an overall 50\% increase in project and institutional money. A main aim is to concentrate and coordinate resources. Project money for the DHGP will increase from DM44 million (US\$21 million) to DM66 million.

Germany's resource centres, which provide genomics services such as the creation, archiving and distribution of clone libraries for research groups, were set up with temporary funding, and they will now become permanent bodies.

A series of competitions will be launched

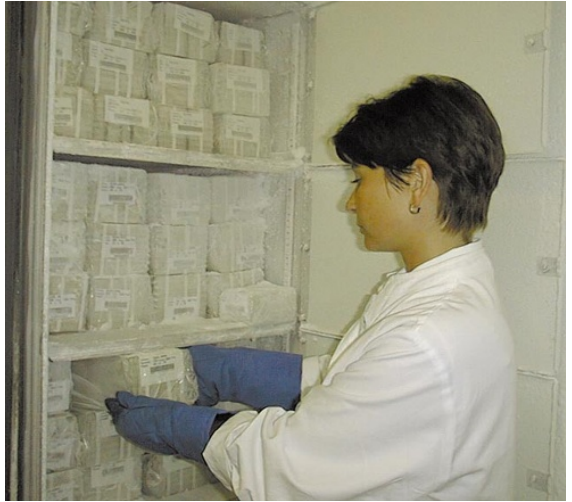

Help at hand: resource centres will be permanent.

to support regional collaboration between industry and academic researchers. One will select three 'competence' centres, or networks, which will receive money from a DM100 million fund; this must be matched by money from other sources. The DHGP will receive a further DM50 million to distribute between these centres.

A major effort in microorganism genomics will be launched using DM40 million to support research networks among universities. Money for existing programmes in plant genomics and bioinformatics will be increased by around two-thirds. And a DM134 million fund will support proteomics research, the analysis of protein profiles.

"We're happy," says Rudi Balling, head of mammalian genetics at the Munich-based GSF national research centre and a member of the DHGP scientific coordinating committee. "Both the money and the psychology are right." Balling points out that it is the first time that the Social Democrats, the major coalition partner in the government, have made a strong commitment to genomics. "They have always been rather vague, but now it seems they are really 'outing' themselves."

"The size of the announced increase has taken us by surprise," says Detlev Ganten, president of the Helmholtz Society, the umbrella group for Germany's 16 national research centres. "The research ministry's plans are very close to what the scientific community has been lobbying for."

Ganten was one of 30 key German scientists who signed a memorandum circulated last week calling for a more concerted effort in support of genome research from both the public and private sectors. The ministry's move will encourage private investment in genomics, he says.

Catenhusen, who has lobbied relentlessly for genomics for more than a decade, is basking in the positive response. "As a politician, I can tell you this programme is an extraordinary success, considering we started from virtually nothing."

But not all are happy. André Rosenthal, professor of molecular biology at the University of Jena and managing director of the Berlin-based genomics company MetaGen, says that, even with the increase, Germany will still be spending only a third of what the Deutsche Forschungsgemeinschaft, Germany's university granting agency, said two years ago was necessary to catch up with the United States.

Moreover, he says, the competence networks and centres are predestined to be based in Berlin, Munich and Heidelberg, since they are intended to build on existing concentrations of research. "It is not real competition - smaller centres will not get a look in," he complains.

\section{...but proposed panel may hamper Italian gene researchers}

Significant aspects of genomics research in Italy will be controlled by a three-member panel of experts nominated by parliament, if a private member's bill is successful.

The bill was approved last week by the culture and education committee of the Italian Senate, but still has some hurdles to clear before becoming law.

The panel would have a seven-year mandate. Based on advice from expert committees, it would make final decisions about what type of basic and applied research could be done, taking into account both bioethical and safety issues, and with responsibility for ensuring 'a balance of ethical positions' within the research community.
The panel, whose creation was initially proposed by senator Valentino Martelli, would not distribute research money, but would have the power to block funds distributed by other agencies for research it considered unsuitable. Ultimately, it would have the power to close laboratories conducting research outside its guidelines.

The move has wide support across different political parties. But many scientists see it as a clumsy response to ethical concerns about human genome research, claiming that it is illthought-out and makes no reference to existing national bioethical and scientific advisory committees. Research minister Ortensio Zecchino has also expressed reservations, but a private member's bill does not require government support to be debated.

Although the bill is fast-tracked and has considerable cross-party support, it may not be approved in the current government's legislative period, not least because of its high proposed running costs of IL40 billion (US\$19.6 billion).

Its lack of reference to existing structures highlights the poor coordination of genomics research in Italy, which was among the first countries after the United States to institute a genomics-research programme. The programme, an initiative of the Italian national research council (CNR), was led by Nobel laureate Renato Dulbecco. It was launched with only IL2 billion, and funding stopped in 1996 when the CNR came under political pressure to reform.

The CNR is now launching a new genomics-research programme intended to prepare the ground for a more extensive initiative. Its IL1.9 billion budget is less than one-twentieth the annual running costs proposed for the planned controlling panel.

Zecchino responded to last week's announcement of the human genome draft sequence by pledging to create a high-level school for molecular medicine, with sites in Milan and Naples. But he gave no details. 